\title{
Heavy Metals in Paddy Soils of Brunei Darussalam and Their Relationship with Selected Soil Properties
}

\author{
Kyi Pyar Zin ${ }^{1,4}$, *, L. H. Lim¹, J. M. R. Sarath Bandara², H. M. Thippeswamy ${ }^{3}$ \\ ${ }^{1}$ Chemical Sciences, Faculty of Science, Universiti Brunei Darussalam, Brunei Darussalam \\ ${ }^{2}$ Environmental and Life Sciences, Faculty of Science, Universiti Brunei Darussalam, Brunei Darussalam \\ ${ }^{3}$ Soil Science and Plant Nutrition Unit, Crop Industry Division, Department of Agriculture and Agrifood, Ministry of Primary Resources and \\ Tourism, Brunei Darussalam \\ ${ }^{4} \mathrm{~A}-1$, Irrigation Compound, $81 / 2$ Mile, Republic of the Union of Myanmar
}

\section{Email address:}

zin.kyipyar@gmail.com (K. P. Zin), 13h0303@ubd.edu.bn (K. P. Zin)

${ }^{*}$ Corresponding author

\section{To cite this article:}

Kyi Pyar Zin, L. H. Lim, J. M. R. Sarath Bandara, H. M. Thippeswamy. Heavy Metals in Paddy Soils of Brunei Darussalam and Their Relationship with Selected Soil Properties. International Journal of Environmental Monitoring and Analysis. Vol. 5, No. 3, 2017 , pp. 64-72. doi: 10.11648/j.ijema.20170503.11

Received: March 7, 2017; Accepted: March 23, 2017; Published: April 13, 2017

\begin{abstract}
In Brunei Darussalam, available information of heavy metals in agricultural soils is sparse and hence a baseline study was carried out on soils in rice growing areas. In this study, trace elements as well as common soil characteristics were determined from twenty six of major rice fields such as Wasan, Limau Manis, Selapon and Lot Senkuang. Al, Fe, Mn and Cd were high in these areas however; $\mathrm{Cu}, \mathrm{Zn}, \mathrm{Cr}, \mathrm{Co}, \mathrm{Ni}$ and $\mathrm{Pb}$ were below safety limit of soil while $\mathrm{Mn}$ and $\mathrm{Cd}$ were above the permissible limit according to the $\mathrm{WHO} / \mathrm{CCME} /$ European Union guidelines. The variations in metal concentrations in these samples are highly correlated to the acidic condition, organic matter and CEC of the paddy soils. The distributions of $\mathrm{Al}, \mathrm{Fe}$, $\mathrm{Cu}, \mathrm{Mn}, \mathrm{Cd}, \mathrm{Cr}, \mathrm{Co}, \mathrm{Pb}$ were high at low $\mathrm{pH} . \mathrm{Cu}, \mathrm{Zn}, \mathrm{Cd}, \mathrm{Ni}$ and $\mathrm{Pb}$ showed positive correlation with organic matter while the quantities of $\mathrm{Al}, \mathrm{Fe}, \mathrm{Mn}, \mathrm{Cr}$ and $\mathrm{Co}$ were negatively correlated. Correlation analyses showed that the $\mathrm{Cd}, \mathrm{Zn}$ and $\mathrm{Ni}$ were associated with CEC while most of the metals were related to $\mathrm{Al}$ and Fe. The soils of the studied areas are extremely acidic with $\mathrm{pH}$ 3.0-4.6, and low in cations, $\mathrm{CEC}$ and available $\mathrm{P}$, while having a high OM content. Low content of $\mathrm{P}$ was due to high amount of $\mathrm{Al}$ and $\mathrm{Fe}$ in these areas.
\end{abstract}

Keywords: Heavy Metals, Soil Acidity, Aifisols, Histosols, Vertisols

\section{Introduction}

A great deal of attention has been paid towards the monitoring of heavy metals (HMs) in recent years due to concern over their effects on human health [51]. The contamination of soils by HMs has emerged from natural origin (parent materials) and anthropogenic actions such as improper use of agrochemicals, animal manures and some activities of industrialization [56, 75]. Dissolving of metals by the oxidation of sulphidic materials has been observed to occur in acid sulphate soils (A. S) [76] which are widespread throughout Brunei Darussalam [30]. The total worldwide area of A. S soils is about 17-24 million hectares [6] and these soils release massive amounts of acid and toxically high contents of metals which disturb the surrounding environment [28]. This process can have a detrimental impact on the agriculture sector as the acidity and the increase of soluble metals result in toxicity and a decrease in nutrient availability of some nutrients, which lowers productivity [23]. In agriculture system, the amount of HMs in soils is an important factor because a high level of HMs deteriorates soil quality and threatens food security [41]. It is also harmful to human health and sustainability of agricultural land such as soil and water pollution and phytotoxicity, failure of crop growth and quality $[15,77]$.

Availability of HMs is influenced by $\mathrm{pH}$, organic matter $(\mathrm{OM})$, cation exchange capacity (CEC), calcium carbonate, $\mathrm{Fe}$ and $\mathrm{Mn}$ oxides [70]. Among them, $\mathrm{pH}$ was the main 
influence of metal solubility in soil and soil solution as well [85]. The second factor is the OMcontent in soil which is also affecting the availability of heavy metals as it retains the HMs in soil and hence enhances crop metal availability [50]. Soil contamination became hazardous due to the continuous degradation of soil OM into the environments reported by [27]. Humic acids, which are the main part of soil OM, represent the heart of the interaction process of inorganic pollutants with soil [25]. The evaluation of soil quality and status of soil HMs is an excellent step to be taken for protecting not only the environment but also sustaining the agriculture system to ensure the health and safety of the consumers [49]. Usually, the concentration of HMs in soils, resulting from parent materials, is not high enough to damage human health. However, anthropogenic sources such as industrialization, agrochemical and other man made factors cause an increase in the HMs content in soil [8]. Accumulation of HMs in soils affects the soil function, crop growth and development as well as human health [44].

However, no sufficient information on HMs in agricultural soils in Brunei Darussalam is available. Only arsenic and cadmium studies have been carried out by [30]. Currently, studies of HMs pollution in soil and crop and their special effects on the human health has happened an important topic among the world. Decreasing of crop production and quality was affected by growing in heavy metals contamination of soil and then more than acceptable limit of HMs content in crops also be risky of consumers' health. Phosphate fertilizers and irrigation water contaminated with $\mathrm{Cd}$ will leach into the soil and water reservoirs, and finally transfer along thefood chain, causing chronic renal failure amongst consumers [12]. Phosphatic fertilizer and other sources include farmyard manure, sewage sludges are the most common source of $\mathrm{Cd}$ contamination of agricultural soils [5, 57]. $\mathrm{Cd}$ is readily taken up by plant root which is then translocated to above ground tissues [81]. This poses a potential threat to human health as it enters the food chain [53]. Food intake and tobacco smoking is the main route where Cd enters the body [48]. So this study was carried out the following objectives: (1) to determine the concentrations of $\mathrm{Cd}, \mathrm{Co}, \mathrm{Cr}, \mathrm{Fe}, \mathrm{Cu}, \mathrm{Mn}, \mathrm{Zn}, \mathrm{Ni}, \mathrm{Pb}$ and $\mathrm{Al}$ in soils from major paddy plantation areas in Brunei Darussalam and (2) to study the correlation of HMs with soil properties.

\section{Methodology}

\subsection{Study Site}

Brunei Darussalam is located in the northern region of Borneo Island, bordering the South China Sea and the Malaysian state of Sarawak. This area is well known for its equatorial climate, characterized by uniformly high temperatures and rainfall throughout the year with average temperature of $27.5^{\circ} \mathrm{C}$ and average precipitation of over 2800 $\mathrm{mm}$ per year. Brunei has four administrative districts, namely Brunei-Muara, Tutong, Belait and Temburong. The study was carried out on four agricultural development areas (Wasan, Limau Manis (LM), Selapon and Lot Senkuang (LS)). Wasan and Limau Manis (LM) are located in the Brunei-Muara District; Selapon is in the Temburong District and Lot Senkuang (LS) is in the Belait District (Figure. 1). According to [32], the soil types of studied areas were fall into different categories as follow: Wasan- Vertisols, Limau ManisVertisols and Histosols, Selapon- Alfisols and Lot SenkuangHistosols.

\section{Location Map of Soil Sampling Area}

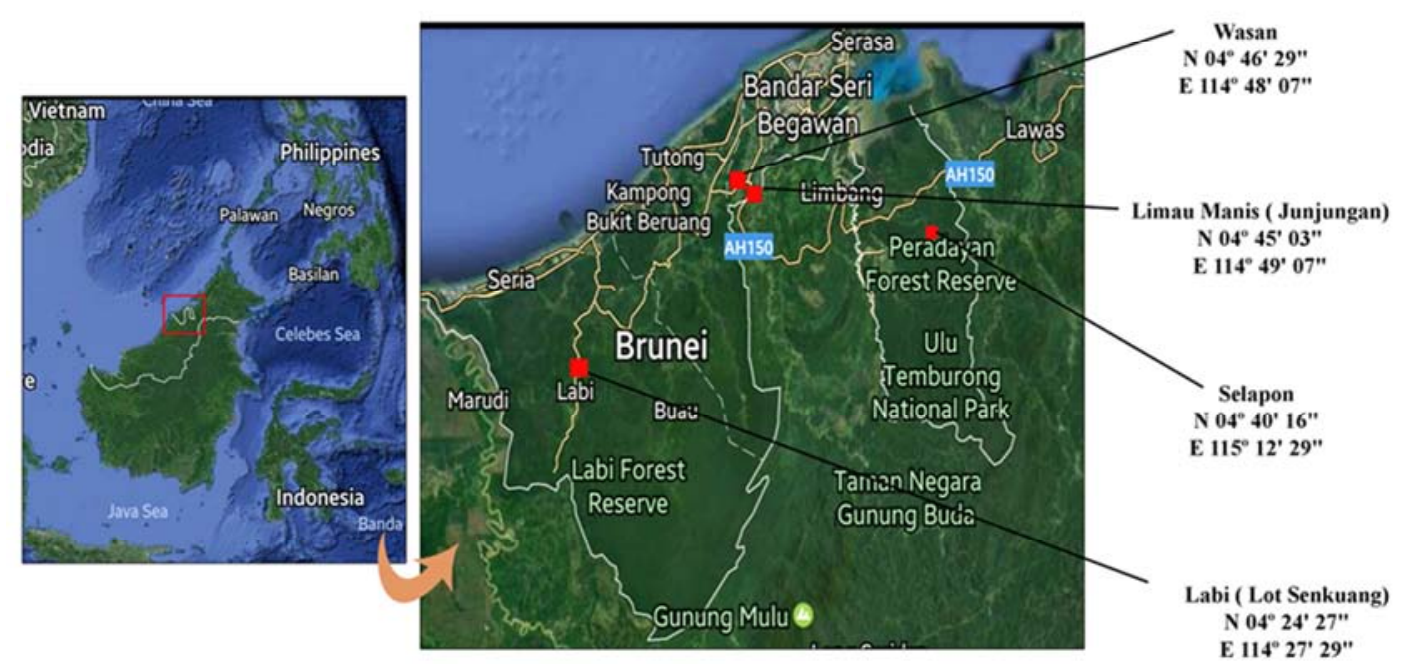

Figure 1. Location of study areas in Brunei Darussalam.

\subsection{Sampling and Chemical Analysis}

Twenty-six surface samples (to a depth of $20 \mathrm{~cm}$ ) from Wasan (W1-W7), Limau Manis (LM1-LM7), Selapon (S1-
S7) and Lot Senkuang (LS1-LS5) were collected. Prior to laboratory analysis, the samples were dried for 5 days at $40^{\circ} \mathrm{C}$ and passed through a $2 \mathrm{~mm}$ sieve. For the determination of $\mathrm{OM}$, the $2 \mathrm{~mm}$ soils were further sieved 
through a $0.2 \mathrm{~mm}$ sieve. All analysis was done in triplicate. The measurement of soil $\mathrm{pH}$ and EC (1:2.5 soil-water) was performed by using a $\mathrm{pH}$ meter (GP 353 ATC) and a conductivity meter (DDS-307). Walkley and Black's method was used for determining the $\mathrm{OM}$ with $5 \mathrm{~mL}$ of potassium dichromate (1M), sulphuric acid (95-97\%) and orthophosphoric acid (85\%) [72]. CEC was determined as summation of calcium, magnesium, sodium and potassium [79]. These cations were extracted with $1 \mathrm{M} \mathrm{NH} \mathrm{NH}_{4} \mathrm{OAc}$ solution (1:10) and measured with an inductively coupled plasma optical emission spectroscopy (ICP-OES, Thermo Scientific iCAP6000 ICP). The available phosphorus (P) and total $\mathrm{P}$ was determined by Bray $\mathrm{I}$ and the nitric acid digestion method, respectively. For Bray $1 \mathrm{P}$, two grams of soil was extracted with $\mathrm{NH}_{4} \mathrm{~F}(0.03 \mathrm{M})$ and $\mathrm{HCl}(0.025 \mathrm{M})$ solution and mixtures were shaken at $180 \mathrm{rpm}$ for five minutes and then filtrated through a What man No. 2 filter paper [72] and analyzed by the ascorbic acid method [52] using a UV colorimetric absorption spectrophotometry. The content of HMs was extracted by hot plate extraction according to the acid digestion of soil, Method 3050B (69). One gram of soil was mixed with $10 \mathrm{~mL}$ of concentrated nitric acid (65\%) in a $250 \mathrm{~mL}$ beaker and the slurry was covered through a watch glass and heated to $95^{\circ} \mathrm{C} \pm 5^{\circ} \mathrm{C}$ for ten minutes without boiling. After the sample was cooled, $5 \mathrm{~mL}$ of concentrated nitric acid was added and the solution was then heated to $95^{\circ} \mathrm{C} \pm 5^{\circ} \mathrm{C}$ for thirty minutes until no brown fumes appeared. After cooling, $10 \mathrm{~mL}$ of hydrogen peroxide (30\%) was added followed by warming until no change in the appearance of the sample was observed. Subsequently $10 \mathrm{~mL}$ of hydrochloric acid (35.4\%) was added and the sample was heated to $95^{\circ} \mathrm{C} \pm 5^{\circ} \mathrm{C}$ for fifteen minutes. The cooled sample was then centrifuged at $3000 \mathrm{rpm}$ for ten minutes and the supernatant solution was kept at $5^{\circ} \mathrm{C}$ until analysis. Prior to heavy metal analysis, all glassware and polyethylene bottles were soaked in $10 \%$ nitric acid for 24 hours and rinsed with ultrapure water. For quality control, method blank and soil certified reference material (CRM, SQC-001) were analyzed and determined by ICP-OES.

\subsection{Statistical Analysis}

All of the parameters are expressed as mean and standard error values in tables. In graphic representations only mean values are used. The relationships between heavy metal and soil chemical properties are expressed as Pearson's linear correlation coefficients using SPSS 21 (36).

\section{Results and Discussion}

\subsection{Chemical Properties}

The performances of the USEPA extraction method 3050B as well as the ICP analytical method for metals analysis in soil samples were tested using the CRM (SQC-001) for metals in soil. The experimental results together with the certified values of the CRM and their standard deviations are summarized in Table 1. As can be seen from Table 1, the results compare favorably with the certified values and the recovery percentages were in the range of 86 to 120 . Therefore, the tested method was acceptable for the analysis of heavy metals in soil.

Table 1. Experimental parameters used and percentage recovery of heavy metals from the analysis of the CRM SQC-001 samples.

\begin{tabular}{|c|c|c|c|c|c|c|}
\hline No. & Element & $\begin{array}{l}\text { Wavelength of ICP } \\
\text { analysis (nm) }\end{array}$ & $\begin{array}{l}\mathbf{R}^{2} \text { value of } \\
\text { calibration curve }\end{array}$ & $\begin{array}{l}\text { Certified value } \\
(\mathrm{mg} / \mathrm{kg})\end{array}$ & $\begin{array}{l}\text { Measured value }(\mathrm{mg} / \mathrm{kg}) \\
(\text { No of analysis }=3)\end{array}$ & Recovery (\%) \\
\hline 1 & $\mathrm{Cd}$ & 214.4 & 0.995 & $123(2)$ & $141(15)$ & 114.8 \\
\hline 2 & $\mathrm{Co}$ & 228.6 & 0.997 & $50.9(1.1)$ & $52.0(8.8)$ & 102.1 \\
\hline 3 & $\mathrm{~Pb}$ & 220.3 & 0.994 & $108(2)$ & $93(12)$ & 86.3 \\
\hline 4 & $\mathrm{Ni}$ & 221.6 & 0.998 & $285(4)$ & $265(20)$ & 93.0 \\
\hline 5 & $\mathrm{Fe}$ & 371.9 & 0.999 & $5230(142)$ & $5261(89)$ & 100.6 \\
\hline 6 & $\mathrm{Cu}$ & 224.7 & 0.999 & $211(3)$ & $213(18)$ & 100.9 \\
\hline 7 & $\mathrm{Mn}$ & 403.1 & 0.999 & $133(5)$ & $122(13)$ & 91.4 \\
\hline 8 & $\mathrm{Zn}$ & 481.0 & 0.981 & $203(5)$ & 197 (14) & 97.1 \\
\hline 9 & $\mathrm{Al}$ & 308.2 & 0.997 & $8100(954)$ & 8048 (104) & 99.4 \\
\hline 10 & $\mathrm{Cr}$ & 283.5 & 0.993 & $63.2(1.7)$ & $74.8(10.0)$ & 118.4 \\
\hline
\end{tabular}

* Mean values are followed by standard deviations in brackets.

Table 2. Chemical characteristics of soil samples collected from four major rice growing areas.

\begin{tabular}{|c|c|c|c|c|c|}
\hline Soil parameters & Wasan $(n=21)$ & Limau Manis $(n=21)$ & Selapon $(n=21)$ & Lot Senkuang $(n=15)$ & All Locations Pooled \\
\hline $\mathrm{pH}$ & $3.6(0.1)$ & $3.6(0.1)$ & $3.9(0.0)$ & $4.2(0.0)$ & $3.8(0.1)$ \\
\hline $\mathrm{EC}(\mathrm{dS} / \mathrm{m})$ & $0.074(0.000)$ & $0.068(0.000)$ & $0.071(0.000)$ & $0.073(0.000)$ & $0.072(0.000)$ \\
\hline OM $(\%)$ & $9.8(0.7)$ & $11.4(1.2)$ & $8.0(0.3)$ & $5.7(0.2)$ & $8.7(0.6)$ \\
\hline Available P (mg/kg) & $6.3(0.9)$ & $9.7(1.8)$ & $6.2(1.0)$ & $2.4(0.1)$ & $6.2(1.0)$ \\
\hline $\mathrm{Ca}(\mathrm{cmol}(\mathrm{c}) / \mathrm{kg})$ & $1.25(0.08)$ & $1.64(0.21)$ & $0.93(0.04)$ & $0.79(0.02)$ & $1.15(0.09)$ \\
\hline $\mathrm{Mg}(\mathrm{cmol}(\mathrm{c}) / \mathrm{kg})$ & $1.14(0.10)$ & $1.16(0.12)$ & $0.81(0.07)$ & $0.20(0.03)$ & $0.83(0.08)$ \\
\hline $\mathrm{Na}(\mathrm{cmol}(\mathrm{c}) / \mathrm{kg})$ & $0.14(0.01)$ & $0.14(0.01)$ & $0.12(0.02)$ & $0.14(0.01)$ & $0.14(0.01)$ \\
\hline $\mathrm{K}(\mathrm{cmol}(\mathrm{c}) / \mathrm{kg})$ & $0.24(0.01)$ & $0.21(0.01)$ & $0.17(0.01)$ & $0.20(0.00)$ & $0.21(0.01)$ \\
\hline $\mathrm{CEC}(\mathrm{cmol}(\mathrm{c}) / \mathrm{kg})$ & $2.7(0.2)$ & $3.1(0.3)$ & $2.0(0.1)$ & $1.4(0.0)$ & $2.3(0.2)$ \\
\hline
\end{tabular}

* Mean values are followed by standard error in brackets. 
The chemical properties ( $\mathrm{pH}, \mathrm{EC}, \mathrm{OM}$, available $\mathrm{P}, \mathrm{Ca}$, $\mathrm{Mg}, \mathrm{Na}, \mathrm{K}$ and $\mathrm{CEC}$ ) of the surface soil samples are summarized in Table 2. Soil $\mathrm{pH}$ is of prime importance in controlling the availability of micronutrients, since it affects directly their solubility as well as mobility activity in the soil environment $(21,22)$. The mean $\mathrm{pH}$ value was extremely acidic (3.8) according to the [63]. The $\mathrm{pH}$ range varied from 3.6 to 4.2 among sample sites which may be due to the climate and geology of the region and studies have shown the presence of pyrites in the soil [30]. Additionally, the aciditymay be caused by the acceleration of the leaching of basic cations from the soil by rainfall [20]. A wide range of strongly acidic soils or acid sulphate soils occur in Brunei Darussalam due to the organic-rich materials, sulphidic material and sulphuric horizons reported by [31]. This $\mathrm{pH}$ level is critical and it has negative influence on the production potential of the crop because the acceptable $\mathrm{pH}$ level for most of the crops is in the range of 5.5-6.5. At low soil $\mathrm{pH}$, microbial activity declines and nutrients such as phosphorus, calcium, magnesium and molybdenum become less available. Furthermore, these extremely acidic conditions favour the mobility and availability of heavy metals in the soil $[17,73]$. The lower pH of the Wasan and Limau Manis (3.6) compared with that of the Selapon (3.9) and Lot
Senkaung (4.2) may partially due to the leaching of coarser texture of the soils and exchangeable cations. In addition, an agricultural area of Wasan and Limau Manis are more developed and with higher usage of inorganic fertilizer which might lead to nitrification and acidification processes [46]. Moreover, sulphidic and sulphuric mineral soils in Brunei Muara district (Wasan and Limau Manis) attributes affect the soil $\mathrm{pH}$.

The mean value of the EC was $0.072 \mathrm{dS} / \mathrm{m}$ which indicates non-saline conditions according to [60]. With the range of $0.068-0.074 \mathrm{dS} / \mathrm{m}$ among the four study areas, these findings indicate thatthere is no major difference in cumulative salt accumulation among the study areas. Nonsaline conditions in Brunei Darussalam agricultural areas may be due to continuous rainfall with higher intensity than evaporation rate [43]. In this study, the average OM content was high $(8.7 \%)$ according to [18]. Among the areas, the range of organic matter differs which may be depend on the soil types, texture, topographic setting and climate conditions such as rainfall, temperature and humidity affect the rate of OM decomposition. Lot Senkuang has the lowest amount of OM $(5.7 \%)$ which may be the effect of sandy texture, steep slopes and erosion hazard.

Table 3. Interpretation of the soil fertility condition.

\begin{tabular}{|c|c|c|c|c|c|c|}
\hline Test name & Unit & Very Low & Low & Moderate & High & Very High \\
\hline Phosphorus (Bray P1) & $\mathrm{mg} / \mathrm{kg}$ & & $<20$ & $20-40$ & $40-100$ & $>100$ \\
\hline CEC & $\mathrm{Cmol}(\mathrm{c}) / \mathrm{kg}$ & $<6$ & $6-12$ & $1-25$ & $25-40$ & $>40$ \\
\hline Extractable calcium & $\mathrm{Cmol}(\mathrm{c}) / \mathrm{kg}$ & - & $<5$ & $5-10$ & $>10$ & - \\
\hline Extractable sodium & $\mathrm{Cmol}(\mathrm{c}) / \mathrm{kg}$ & $0-0.1$ & $0.1-0.3$ & $0.3-0.7$ & $0.7-2$ & $>2$ \\
\hline Exchangeable potassium & $\mathrm{Cmol}(\mathrm{c}) / \mathrm{kg}$ & $0-0.2$ & $0.2-0.3$ & $0.3-0.7$ & $0.7-2$ & $>2$ \\
\hline
\end{tabular}

Source: [62]

Table 4. Statistical analysis of toxic metals in soil.

\begin{tabular}{|c|c|c|c|c|c|c|c|c|}
\hline \multirow{2}{*}{$\begin{array}{l}\text { Heavy metals } \\
(\mathrm{mg} / \mathrm{kg})\end{array}$} & \multirow{2}{*}{$\begin{array}{l}\text { Wasan } \\
(n=21)\end{array}$} & \multirow{2}{*}{$\begin{array}{l}\text { Limau Manis } \\
(n=21)\end{array}$} & \multirow{2}{*}{$\begin{array}{l}\text { Selapon } \\
(n=21)\end{array}$} & \multirow{2}{*}{$\begin{array}{l}\text { Lot Senkuang } \\
(\mathrm{n}=15)\end{array}$} & \multirow{2}{*}{$\begin{array}{l}\text { All locations } \\
\text { pooled }\end{array}$} & \multicolumn{3}{|c|}{ Agricultural soil quality guidelines } \\
\hline & & & & & & [16] & [24] & [79] \\
\hline $\mathrm{Al}$ & $\begin{array}{l}9906.1 \\
(286.9)\end{array}$ & $\begin{array}{l}10123.2 \\
(558.6)\end{array}$ & $\begin{array}{l}9192.3 \\
(192.1)\end{array}$ & $\begin{array}{l}12847.9 \\
(538.7)\end{array}$ & $\begin{array}{l}10338.1 \\
(247.9)\end{array}$ & NA & NA & NA \\
\hline $\mathrm{Fe}$ & $\begin{array}{l}13447.9 \\
(456.9)\end{array}$ & $\begin{array}{l}9748.7 \\
(855.4)\end{array}$ & $\begin{array}{l}22598.7 \\
(192.1)\end{array}$ & $\begin{array}{l}14220.6 \\
(1217.7)\end{array}$ & $\begin{array}{l}15064.2 \\
(655.6)\end{array}$ & NA & NA & NA \\
\hline $\mathrm{Cu}$ & $\begin{array}{l}3.9 \\
(0.7)\end{array}$ & $\begin{array}{l}12.4 \\
(1.0)\end{array}$ & $\begin{array}{l}3.4 \\
(0.5)\end{array}$ & $\begin{array}{l}17.1 \\
(1.9)\end{array}$ & $\begin{array}{l}9.1 \\
(0.8)\end{array}$ & 63 & 140 & 30 \\
\hline $\mathrm{Mn}$ & $\begin{array}{l}32.6 \\
(10.9)\end{array}$ & $\begin{array}{l}16.7 \\
(2.0)\end{array}$ & $\begin{array}{l}406.1 \\
(26.1)\end{array}$ & $\begin{array}{l}25.3 \\
(2.0)\end{array}$ & $\begin{array}{l}127.5 \\
(20.7)\end{array}$ & NA & NA & 80 \\
\hline $\mathrm{Zn}$ & $\begin{array}{l}32.2 \\
(2.5)\end{array}$ & $\begin{array}{l}50.0 \\
(7.6)\end{array}$ & $\begin{array}{l}3.8 \\
(1.1)\end{array}$ & $\begin{array}{l}54.7 \\
(15.1)\end{array}$ & $\begin{array}{l}34.4 \\
(4.9)\end{array}$ & 200 & NA & 200 \\
\hline $\mathrm{Cd}$ & $\begin{array}{l}4.7 \\
(0.3)\end{array}$ & $\begin{array}{l}11.0 \\
(0.9)\end{array}$ & $\begin{array}{l}10.2 \\
(0.3)\end{array}$ & $\begin{array}{l}2.5 \\
(1.6)\end{array}$ & $\begin{array}{l}8.1 \\
(0.5)\end{array}$ & 1.4 & 3.0 & NA \\
\hline $\mathrm{Cr}$ & ND & $\begin{array}{l}37.1 \\
(2.4)\end{array}$ & ND & $\begin{array}{l}45.5 \\
(2.4)\end{array}$ & $\begin{array}{l}38.4 \\
(2.1)\end{array}$ & 64 & 150 & 100 \\
\hline Co & $\begin{array}{l}1.2 \\
(0.5)\end{array}$ & $\begin{array}{l}0.34 \\
(0.28)\end{array}$ & $\begin{array}{l}10.7 \\
(0.3)\end{array}$ & $\begin{array}{l}3.8 \\
(0.3)\end{array}$ & $\begin{array}{l}4.9 \\
(0.5)\end{array}$ & 40 & NA & NA \\
\hline $\mathrm{Ni}$ & $\begin{array}{l}14.3 \\
(5.5)\end{array}$ & ND & $\begin{array}{l}13.3 \\
(1.7)\end{array}$ & $\begin{array}{l}7.5 \\
(2.2)\end{array}$ & $\begin{array}{l}11.7 \\
(2.5)\end{array}$ & 45 & 75 & NA \\
\hline $\mathrm{Pb}$ & $\begin{array}{l}11.0 \\
(0.3)\end{array}$ & $\begin{array}{l}14.1 \\
(0.6)\end{array}$ & $\begin{array}{l}9.1 \\
(0.2)\end{array}$ & $\begin{array}{l}17.3 \\
(1.0)\end{array}$ & $\begin{array}{l}12.6 \\
(0.4)\end{array}$ & 70 & 300 & NA \\
\hline
\end{tabular}

$\mathrm{ND}=$ Not detected (below lowest detection limit $\mathrm{Cr}(0.1590)$ and $\mathrm{Ni}(0.0465) \mathrm{mg} / \mathrm{kg} ; \mathrm{NA}=$ Not available

* Mean values are followed by standard error in brackets. 
The average value of exchangeable cations $(\mathrm{Ca}, \mathrm{Mg}, \mathrm{Na}$ and K) CEC and available Pwas low in these areas according to Table 3. A similar result was also observed by [43]. Here, humid weather accelerates mineral weathering process and strong leakage of cations responsible for depletion of exchangeable cations. No significant difference in soil exchangeable cations content was observed in any of the locations. The lowest CEC $(1.4 \mathrm{cmol} / \mathrm{kg})$ found in Lot Senkuang was dominated by sandy soils, poor organic matter and additionally high $\mathrm{Al}$ content in soils (Table 4) cause a low number of negative charges per unit of soil and high leaching problems. For study areas P fixation is likely to be a problem according to Table 3. Under extremely acid conditions, $\mathrm{P}$ fixation was expected because of $\mathrm{Fe}$ and $\mathrm{Al}$ ions, which combine with $\mathrm{P}$ to form insoluble compounds at low $\mathrm{pH}$ [37]. Among the areas, available $\mathrm{P}(9.7 \mathrm{mg} / \mathrm{kg})$ contents of Limau Manis was a higher than the Wasan (6.3 $\mathrm{mg} / \mathrm{kg})$, Selapon $(6.2 \mathrm{mg} / \mathrm{kg})$ and Lot Senkaung $(2.4 \mathrm{mg} / \mathrm{kg})$; it was due to the decomposition of soil organic matter or organic P amendments. Furthermore, a lower content of Fe $(9748.7 \mathrm{mg} / \mathrm{kg}$ ) in Limau Manis soil compared to those in the areas of Wasan $(13447.9 \mathrm{mg} / \mathrm{kg})$, Selapon $(22598.7 \mathrm{mg} / \mathrm{kg}$ ) and Lot Senkaung (14220.6 mg/kg) according to Table 4 indicates a lower fixation of $\mathrm{P}$ in Limau Manis than the other areas.

\subsection{Heavy Metals Status}

The total heavy metals content of the samples of the areas are presented in Table 4. The Fe content was found to be the most predominant metal amongst all the metals in this study, followed by Al. All the trace metals have mean values below the safety limit of the $[80,16,24]$ guideline except for $\mathrm{Mn}$ and $\mathrm{Cd}$. Reasons attributed are the degradation of soil health as evidenced by the increase in acidity and concentration of $\mathrm{Fe}, \mathrm{Al}, \mathrm{Mn}$ and $\mathrm{Cd}$ to toxic levels. Soil metal content was mainly contributed by parent materials, topography, acidic condition and additionally iron oxides and hydroxides accumulate trace elements through the adsorption mechanism [58, 84, 54, 42]. In highly acidic soils, the mobility of metallic elements is much higher than in soils with neutral and alkaline reaction $[4,71]$.

Large quantityof $\mathrm{Cd}$ was found in Limau Manis (11.0 $\mathrm{mg} / \mathrm{kg}$ ) and Selapon $(10.2 \mathrm{mg} / \mathrm{kg})$; it was mainly from the $\mathrm{P}$ content and manganese oxide of soil. According to Table 3 and 4, Limau Manis and Selapon have the highest amount of P $(9.7 \mathrm{mg} / \mathrm{kg})$ and manganese $(406.1 \mathrm{mg} / \mathrm{kg})$ among the study. The same findings were reported by $[7,13,14] \mathrm{Cd}$ is associated with manganese-oxide in soil andtriple superphosphate (TSP) fertilizer was primary supply of $\mathrm{Cd}$ toward soils as it has $0.1-170 \mathrm{mg} / \mathrm{kg}$ of $\mathrm{Cd}$. We observed that TSP used by Brunei Darussalam carried $2.87 \mathrm{mg} / \mathrm{kg}$ of $\mathrm{Cd}$. Application of fertilizer influence $\mathrm{Cd}$ content in soil and fertilizers affect $\mathrm{Cd}$ movement of plant roots and Cd uptake of plant [78]. Wasan and Selapon areas have more Ni concentration than other areas; and sources of $\mathrm{Ni}$ could be from the weathering of minerals which contributes to the increased mobilization of $\mathrm{Ni}$ [61].

According to Table 4, Brunei soils have found very high concentration of Fe (average value $15064.2 \mathrm{mg} / \mathrm{kg}$ ). This was attributed to predominantly iron pyrite [29] and leaching of iron from soil at low $\mathrm{pH}$ conditions. Furthermore, the equatorial climatic condition of Brunei Darussalam which favors weathering process and origin of parent materials may be high level of $\mathrm{Fe}$ concentration in the soils. A higher content of Fe $(22598.7 \mathrm{mg} / \mathrm{kg})$ was found in the Selapon as compared to the other areas; it is the different of soil taxonomy in the study areas. Large amounts of Fe in Alfisols resulting in iron- bearing minerals [67] and it is supported to the present study which Selapon areas were fallen the Alfisols order of soil classification [32].

A higher content of $\mathrm{Mn}$ (406.1 mg/kg) and Co (10.7 $\mathrm{mg} / \mathrm{kg}$ ) in Selapon soil compared to Wasan, Limau Manis and Lot Senkaung soil and may be due to the prevalence of soil type and dependent upon mobilization and immobilization processes. Furthermore, the presence of very high values of $\mathrm{Mn}$ in Selapon can be attributed to the presence of Mn-oxides concentrations under anaerobic conditions such as flooding or poor drainage of soil [10]. The high amount of soil Mn in the study area was attributed to the application of various types of pesticides and mineral fertilizers for increasing plant growth and yields [42]. While the high amount of $\mathrm{Co}$ in Selapon may be due to the prolonged waterlooging, the poorly drained type, sulfuric and sulfidic soils [32]. It is accordance with the findings of ATSDR, 2004; Co is mainly as sulphides with $\mathrm{Co}_{3} \mathrm{~S}_{4}$, $\mathrm{CuCo}_{2} \mathrm{~S}_{4}$ being the most common Co minerals.

Most of toxic metals such as $\mathrm{Al}(12847.9 \mathrm{mg} / \mathrm{kg}), \mathrm{Cu}(17.1$ $\mathrm{mg} / \mathrm{kg}), \mathrm{Zn}(54.7 \mathrm{mg} / \mathrm{kg}), \mathrm{Cr}(45.5 \mathrm{mg} / \mathrm{kg})$ and $\mathrm{Pb}(17.3$ $\mathrm{mg} / \mathrm{kg}$ ) were observed at highest solubility in Lot Senkuang compared to Wasan, Limau Manis and Selapon. The amount of metals in soil relied on the soil type; Lot Senkuang soils are organic or peat soils under the Histosols according to [32]. Similarly, [82] reported that peat soils accumulate heavy metals in a much higher amount. Noteworthy, Al has been classified as a contaminant of potential concern only in soils with a $\mathrm{pH}$ of 5.5 or less [68]. This may be the reason why no standards have been set for Al in soil (Table 5). The reason for the high $\mathrm{Al}$ concentration in all the study areas is because $\mathrm{Al}$ is very mobile due to characteristic soil acidic conditions ( $\mathrm{pH}$ 3.6-4.2) which promote aluminosilicate weathering and Al-hydroxide dissolution and thus $\mathrm{Al}$ solubilisation and transport [26]. This result was shown that Al toxicity isamain constraint of plant growth in these areas.

High concentrations of metals could have a potentially negative impact on plants, microorganisms and animals [83]. The concentrations of heavy metals in soil and their impact on ecosystems can be influenced by many factors such as parent material, climate, topography, $\mathrm{pH}, \mathrm{OM}, \mathrm{CEC}$, clay content, soil texture and anthropogenic activities [35, 55]. The correlations between HMs concentrations and soil properties are shown in Table 5. There was significantly positive correlation between the $\mathrm{HM}$ contents ( $\mathrm{Al}, \mathrm{Fe}, \mathrm{Cu}$, 
$\mathrm{Mn}, \mathrm{Cd}, \mathrm{Cr}, \mathrm{Co}, \mathrm{Pb}$ ) and soil $\mathrm{pH}$ values of range from 3.0 to 4.6 except for $\mathrm{Zn}$ and $\mathrm{Ni}$. This finding was in accordance with $[38,33]$ 's observation, where soil acidity influence of mobility and bioavailability HMs in the soil. When $\mathrm{pH}$ falls below 5, metals mobility is enhanced as a result of the increased proton concentration [59]. It is relevant with our results that extremely strong acidic conditions ( $\mathrm{pH}$ value- 3 to 4.6) in the Brunei Soils increased metal availability (Table $5)$. Similar results reported by $[66,2]$; nearly all the metals in higher soil acidic conditions are activated which promote metal uptake of the plant.

Table 5. Correlation of heavy metals versus chemical properties.

\begin{tabular}{|c|c|c|c|c|c|c|c|c|c|c|}
\hline Parameter & Al & $\mathbf{F e}$ & $\mathrm{Cu}$ & Mn & $\mathbf{Z n}$ & Cd & $\mathrm{Cr}$ & Co & $\mathrm{Ni}$ & $\mathbf{P b}$ \\
\hline $\mathrm{pH}$ & $.231 *$ & $.296 * *$ & $.304^{* *}$ & $.274 *$ & -.150 & .067 & .047 & $.465 * *$ & $-.467 * *$ & .141 \\
\hline $\mathrm{OM}$ & -.218 & -.207 & .025 & -.103 & .278 & $.244^{*}$ & -.232 & -.061 & .233 & -.104 \\
\hline CEC & $-.228^{*}$ & $-.264 *$ & -.012 & -.166 & .282 & .225 & -.210 & -.170 & $.344 *$ & -.089 \\
\hline Available P & -.186 & $-.241 *$ & -.165 & -.041 & .239 & $.345 * *$ & -.241 & -.086 & .158 & -.097 \\
\hline $\mathrm{Al}$ & 1 & .079 & $.603 * *$ & $-.263 *$ & $.599 * *$ & $-.387 * *$ & $.840 * *$ & $-.322 * *$ & -.172 & $.704 * *$ \\
\hline $\mathrm{Fe}$ & .079 & 1 & $-.384 * *$ & $.793 * *$ & $-.432 * *$ & -.063 & $.793 * *$ & $.829 * *$ & -.149 & $-.418 * *$ \\
\hline $\mathrm{Cu}$ & $.603 * *$ & $-.384 * *$ & 1 & $-.474 * *$ & $.684 * *$ & -.203 & $.562 * *$ & $-.336 * *$ & -.106 & $.911 * *$ \\
\hline $\mathrm{Mn}$ & $-.263^{*}$ & $.793 * *$ & $-.474 * *$ & 1 & $-.595 * *$ & $.316 * *$ & $.762 * *$ & $.929 * *$ & -.122 & $-.517 * *$ \\
\hline $\mathrm{Cd}$ & $-.387 * *$ & -.063 & -.203 & $.316^{* *}$ & $-.297 *$ & 1 & $-.733 *$ & $.591 * *$ & -.204 & $-.249 *$ \\
\hline $\mathrm{Cr}$ & $.840 * *$ & $.793 * *$ & $.562 * *$ & $.762 * *$ & .325 & $-.733 * *$ & 1 & .448 & - & $.791 * *$ \\
\hline $\mathrm{Co}$ & $-.322 * *$ & $.829 * *$ & $-.336 * *$ & $.929 * *$ & $-.630 * *$ & $.591 * *$ & .448 & 1 & -.209 & $-.412 * *$ \\
\hline $\mathrm{Ni}$ & -.172 & -.149 & -.106 & -.122 & .395 & -.204 & - & -.216 & 1 & -.017 \\
\hline $\mathrm{Pb}$ & $.704 * *$ & $-.418 * *$ & $.911 * *$ & $-.517 * *$ & $.732 * *$ & $-.249 *$ & $.791 * *$ & $-.412 * *$ & -.017 & 1 \\
\hline
\end{tabular}

**; *Correlation is significant at the 0.01 and 0.05 level (2-tailed)

High organic matter (OM) content is favorable for the sorption of HMs in soils. The significant positive correlations between $\mathrm{Cd}$ and $\mathrm{OM}$ obtained in this study (Table 5); it showed that organic matter plays a fundamental role of $\mathrm{Cd}$ contents in soil. According to [74, 50], OM is also involved in supply inorganic chemicals to the soil solution, which may serve as chelates and increase metal availability to plants. However, the $\mathrm{Al}, \mathrm{Fe}, \mathrm{Mn}, \mathrm{Cr}, \mathrm{Co}$ and $\mathrm{Pb}$ contents were negatively correlated with OM (Table 5). Similar results were observed by [11, 19,47] also reported that OM-bound Mn reaches the rhizosphere, the oxidized soil conditions possibly mineralize the OM, which transforms Mn into less available forms.

The results of the correlation analysis (Table 5) indicate that $\mathrm{Cd}, \mathrm{Zn}$ and $\mathrm{Ni}$ were positively correlated with $\mathrm{CEC}$ and available P. It is agreed with $[40,64]$ also found that the total content of micronutrients increased with an increase in CEC and phosphate fertilizers are the main sourceof $\mathrm{Cd}$ contaminant as well. Other metals (Al, Fe, Cu, Mn, Cr, Co and $\mathrm{Pb}$ ) were negatively associated with $\mathrm{CEC}$ and available $\mathrm{P}$. This is great of concern as increased levels of these metals in the environment consequently result in the decreased mineral element composition of the soil. It is expected that available $\mathrm{P}$ has negative correlation with $\mathrm{Al}$ and Fe because of fixation of $\mathrm{Al}$ and $\mathrm{Fe}$. An increasing copper content of soils reduced the amount of plant available $\mathrm{P}$ in soil [3].

Significant and/or positive correlations were also found between most of the trace elements (Table 5), suggesting that they may be mainly associated with the mineral phase in soils. The significant and/or positive correlation is seen between $\mathrm{Al}$ vs. $\mathrm{Fe}, \mathrm{Cu}, \mathrm{Zn}, \mathrm{Cr}, \mathrm{Pb}$. The significant and/or positive correlation is seen between $\mathrm{Fe}$ vs. $\mathrm{Al}, \mathrm{Mn}, \mathrm{Co}$ and $\mathrm{Cr}$ (Table 5). The content of $\mathrm{Fe}$ had a significant positive correlation with $\mathrm{Mn}(\mathrm{r}=.793, \mathrm{P}<0.01)$ as Fe and $\mathrm{Mn}$ are the most abundant metals in the lithosphere, and they generally occur as Fe-Mn oxides and hydroxides, which play an important role in the precipitation or solubility of some heavy metals in soils [39]. The facts that trace element concentrations correlated better with $\mathrm{Fe}$ and $\mathrm{Al}$ suggests that the elements might have co-precipitated with Fe-Al oxides during the formation in soils [65]. Hernandez et al., 2003 and Li et al., 2014 reported that levels of soil HMs are controlled by concentrations of $\mathrm{Al}$ and Fe content [34, 45]. Similarly, the significant positive correlation between $\mathrm{Pb}$ and $\mathrm{Zn}$ in our study can be explained because $\mathrm{Pb}$ was found to coexist with $\mathrm{Zn}$ in the internal growth of a crystal lattice [1].

\section{Conclusion}

The findings from the study have broadened our knowledge on the heavy metals (HMs) content and their possible sources in the agricultural soils, a representative area of the Brunei Darussalam. Based on the safety limits of HMs concentrations in soil, the paddy fields showed high level of $\mathrm{Al}, \mathrm{Fe}, \mathrm{Cd}$ and $\mathrm{Mn}$. This may be due to the parent material, heavy rainfall and/or poor drainage conditions, extremely acidic and high organic matter of the study areas. These factors cause crop failure and decreased production as evidenced by low rice yield (1.7 tons/ha) in Brunei Darussalam compared to other rice producing countries. The study areas have a low fertility status because of extremely acidic condition, low level of $\mathrm{P}$, poor in basic cations and CEC but rich in organic matter content. Soil acidity is one of the most important constraints; when $\mathrm{pH}$ drops below 4.5, it is difficult to produce food crops. Soil acidification and the enrichment of toxic elements are important factors affecting ecological safety. Phosphorus is the most deficient nutrient as a result of the high $\mathrm{P}$ fixing capacity due to presence of $\mathrm{Fe}$ and Al. This may provide basic information for soil fertility management based on the soil properties in the paddy fields. 
Therefore, this study suggests promoting natural and artificial methods that minimize the soil acidity and reduce $\mathrm{Al}, \mathrm{Fe}, \mathrm{Cd}$ and Mn toxicity levels. More studies are neededin order to monitor the relationship between soil properties and HMs content, especially $\mathrm{Al}, \mathrm{Fe}, \mathrm{Cd}$ and $\mathrm{Mn}$.

\section{References}

[1] Acosta, J. A., Martinez-Martinez, S., Faz, A. and Arocena, J., 2011. Accumulations of major and trace elements in particle size fractions of soils on eight different parent materials. Geoderma 161, 30-42.

[2] Adeniyi, A. A., Yusuf, K. O. and Okedeyi, O. O., 2008. Assessment of the exposure of two fish species to metals pollution in the Ogun river catchements, Ketty, Lagos, Nigeria. Environmental Monitoring and Assessment 137, 451-458.

[3] Akinnifesi, T. A., Asubiojo, O. I. and Amusan, A. A., 2006. Effects of fungicide residues on the physico-chemical characteristics of soils of a major cocoa-producing area of Nigeria. Sci. Total Environ 366, 876-879.

[4] Alkorta, I., Hernandez-Alica, J., Becerril, J. M., Amezaga, I., Albizu, I. and Garbisu, C., 2004. Recent findings on the phytoremediation of soils contaminated with environmentally toxic heavy metals and metalloids such as zinc, cadmium, lead and arsenic. Rev Environ SciNio/Tech 3, 71-90.

[5] Alloway, B. J., 1995. Heavy metals in soils. $2^{\text {nd }}$ Ed. Blackie Academic \&Professional An imprint of Chapman \& Hall, UK.

[6] Andriesse, W. and van Mensvoort, M. F., 2002. Distribution and extent of acid sulphate soils. In: Lal R. (ed.), Encyclopedia of soil science, Marcel Dekker Inc., New York, pp. 1-6.

[7] Apokpodion, P. E., Lajide, L. and Aiyedanmi, A. F., 2013. Characterization of heavy metal fractions in agricultural soils using sequential extraction technique. World Journal of Agricultural Sciences 1, 45-52.

[8] Atafar, Z., Mesdaghinia, A., Nouri, J., Homaee, M., Yunesian, M., Ahamadimoghaddam, M. and Mahvi, A. H., 2010. Effect of fertilizer application on soil heavy metal concentration. Environmental Monitoring and Assessment 160, 83-89.

[9] ATSDR., 2004. Agency for Toxic Substances and Disease Registry. Toxicological Profile for cobalt. Atlanta, GA: U. S. Department of Health and Human Services, Public Health Service.

[10] Aydinalp, C. and Marinova, S., 2003. Distribution and forms of heavy metals in some agricultural soils. Polish Journal of Environmental Studies Vol.12 No.5, 629-633.

[11] Ayele, T., Ayana, M., Tanto, T., Asefa, D., 2014. Evaluating the Status of micronutrients under irrigated and rainfed agricultural soils in Abaya Chamo Lake Basin, South-west Ethiopia. Journal of Scientific Research and Reviews Vol.3 (1), 018-027.

[12] Bandara, J. M. R. S., Wijewardena, H. V. P., Bandara, Y. M. A. Y., Jayasooriya, R. G. P. T. and Rajapaksha, H., 2010a. Pollution of River Mahaweli and farmlands under irrigation by cadmium from agricultural inputs leading to a chronic renal failure epidemic among farmers in NCP, Sri Lanka. Environmental Geochemistry and Health doi:

\subsection{7/s10653-010-9344-4.}

[13] Bandara, J. M. R. S., Wijewardena, H. V. P., Liyanege, J., Upul, M. A. and Bandara, J. M. U. A., 2010b. Chronic renal failure in Sri Lanka caused by elevated dietary cadmium: Trojan horse of the green revolution. Toxicology Letters 198, 33-39.

[14] Cakmak, D., Saljnikov, E., Mrvic, V., Jakovljevic, M., Marjanovic, Z., Sikiric, B. and Maksimovic, S., 2010. Soil properties and trace elements following 40 years of phosphate fertilization. J. Environ Qual 39, 541-547.

[15] Calvino, D. F., Suarez, J. A. R., Periago, E. L., Estevez, M. A. and Gandara, J. S., 2008. Copper content of soils and river sediments in a winegrowing area, and its distribution among soil or sediment components. Geoderma 145, 91-97.

[16] CCME, 2014. Canadian environmental soil quality guidelines. Canadian Council of Ministers of the Environment.www.ccme.ca/en/resources/canaidanenvironmental-quality-guidelines.

[17] Cerqueira, B., Vega, F. A., Serra, C., Silva, L. F. O., Andrade, M. L., 2011. Time of flights secondary ion mass spectrometry and high-resolution transmission electron microscopy/energy dispersive spectrometry: A preliminary study of the distribution of $\mathrm{Cu}^{2+}$ and $\mathrm{Cu}^{2+} / \mathrm{Pb}^{2+}$ on a Bt horizon surfaces. J. Hazard. Mater 195, 422-431.

[18] Charman, P. E. V. and Hooper, M. M. 2000. Soil organic matter (SOM). In Charman, P. E. V., Murphy, B. W. eds. Soils: Their properties and management. $2^{\text {nd }}$ Ed. Oxford University Press, pp. 260-270.

[19] Chinchmalatpure, A. R. B. L., Challa, O. and Sehgal, J., 2000. Available micronutrient status of soils on different parent materials and landforms in a micro- watershed of Wunna catchment near Nagpur (Maharashtra). Agropedology 10 (1), 53-58.

[20] Dharumarajan, S. and Singh, S. K., 2014. Variation of soil properties and phosphorus fractions in three cropping systems of lower indo-Gangetic alluvial plain. African Journal of Agricultural Research Vol.9 24, 187-1886.

[21] Diatta, J. B., 2008. Mutual Cu, Fe and Mn solubility control under differentiated soil moisture status. Journal of Elementology 13 (4), 473-489.

[22] Diatta, J. B., Witczak, R. and Skubiszewska, A. 2009. Zinc dynamics in an arable soil as affected by plant residues incorporation: agro environmental concern. Fresenius Environmental Bulletin 18 (10a), 1957-1962.

[23] EPA., 2007. Site contamination-acid sulfate soil materials. EPA Guidelines, Environmental Protection Act, 1-15.

[24] European Union., 2002. Heavy metals in wastes, European Commission on environment. http:// ec. europa. eu/ environment/waste/studies/pdf/heavy metals report.pdf.

[25] Fakhry, A., Osman, O., Ezzat, H. and Ibrahim, M., 2016. Spectroscopic analyses of soil samples outside Nile Delta of Egypt. SpectrochimicaActa Part A: Molecular and Bimolecular Spectroscopy Vol.168 (5), 244-252.

[26] Fältmarsch, R. M., Astrom, M. E. and Vuori, K. M., 2009. Environmental risks of metals mobilized from acid sulphate soils in Finland: a literature review. Boreal Environment Research 13, 444-456. 
[27] Ghabbour, E. A., Davies, G., Ghali, N. K. and Mulligan, M. D., 2001. The effect of temperature on tight metal binding by peat and soil derived solid humic acids. Canadian Journal of Soil Science 81 (3), 331-336. 10.4141/S00-065.

[28] Goasvi, K., Sammut, J., Gifford, S. and Jankowski, J., 2004. Macro algal biomonitors of trace metal concentration in acid sulfate soil aquaculture ponds. Sci Total Env 25, 25-39.

[29] Gomez, M. I., Castro, H. E. and Pacheco, Y. W., 2005. Recovery and management of actual acid sulphate soils in Boyaca (Colombia). AgronomíaColombiana 23 (1), 128-135.

[30] Grealish, G., Fitzpatrick, R., Voase, A. R. and Hicks, W., 2008a. Brunei: Summary of acid sulfate soils. In Inland Acid Sulfate Soil Systems Across Australia (Eds. Rob Fitzpatrick and Paul Shand). pp. 301- 309. CRC LEME Open files Report No. 249. (Thematic Volume) CRC LEME, Perth, Australia.

[31] Grealish, G. J. and Fitzpatrick, R. W., 2013. Acid sulphate soil characterization in Negara Brunei Darussalam: a case study to inform management decisions. Soil Use and Management September 29, 432-444.

[32] Grealish, G. J., Ringrose-Voase, A. J., Fitzpatrick, R. W., Wong M. T. F. and Winston, E. C., 2008b. Soil fertility evaluation/advisory Service in Negara Brunei Darussalam Volume 1 - soils and land Suitability of the agricultural development areas'. Science Report 57/08. CSIRO Land and Water, Australia.

[33] Haliru, H. A., Ling, L. P. and Suhaiza, S. O., 2014. Heavy metal concentration levels in soil at Lake Geriyo irrigation site, Yola, Adamawa state, North Eastern Nigeria. International Journal of Environmental Monitoring and Analysis 2 (2), 106-111.

[34] Hernandez, L., Probst, A., Probst, J. and Ulrich, E., 2003. Heavy metal distribution in some French forest soils: evidence for atmospheric contamination. Sci Total Environ 312, 195219.

[35] Hooda, P. S., 2010. Trace elements in soils. Wiley publication, pp. 596 .

[36] IBM Statistics., 2012. SPSS Version 21. Property of IBM Corp. (C) Copyright IBM cooperation and its licensors 1989.

[37] Issaka, R. N., Senayah, J. K., Andoh-Mensah, E. and Ennin, S. A., 2012. Assessment of fertility status of soils supporting coconut (Cocusnucifera) cultivation in Western and central regions of Ghana. West African Journal of Applied Ecology Vol. 20 (1), 47-56.

[38] Jan, F. A., Ishaq, M., Khan, S., Ihasanullah, I., Ahmad, I. and Shakirullah, M. 2010. A comparative study of human health risks via consumption of food crops grown on wastewater irrigated soil (Peshawar) and relatively clean water irrigated soil (Lower Dir). J. Hazard. Mat 179, 612-621.

[39] Jones, C. and Jacobsen, J., 2009. Micronutrients: Cycling, testing and fertilizer recommendations. Nutrient management modules 7, \#4449-7, Montana State University Extension Service, Bozeman, Montana.

[40] Kasa, E., Felix-Henningsen, P., Duering, R. A. and Gjoka, F., 2014. The occurrence of heavy metals in irrigated and nonirrigated arable soils, NW Albania. Environmental Monitoring and Assessment 186, 3595-3603.

[41] Kelepertzis, E., 2014. Accumulation of heavy metals in agricultural soils of Mediterranean: Insights from Argoloda basin, Peloponnese, Greece. Geoderma 221-222, 82-90.

[42] Khairiah, J., Tharmendren, M. S. M., Habibah, J., Zulkefly, H., Wan Kamal, W. I. and Ismail, B. S., 2012. Heavy metal content in paddy soils of Ketara, Besut, Terengganu, Malaysia. World Applied Sciences Journal 19 (2), 183-191.

[43] KyiPyarZin, Lim, L. H., ThippeswamyHoligeMallikarjunaiah. And SarathBandara, J. M. R., 2015. Chemical properties and phosphorus fractions in profiles of acid sulfate soils of major rice growing areas in Brunei Darussalam. Geoderma Regional $622-30$.

[44] Lee, C. S. L., Li, X., Shi, W., Cheung, S. C. N. and Thornton, L. 2006. Metal contamination in urban, suburban and country park soils of Hong Kong: A study based on GIS and multivariate statistics. Sci. Total Environ Vol.356 (1-3), 45-61.

[45] Li, Y., Zhang, H., Chen, X., Tu, C., Luo, Y. and Christie, P. 2014. Distribution of heavy metals in soils of the Yellow River Delta: concentrations in different soil horizons and source identification. J Soils Sediments 14, 1158-1168.

[46] Liang, Q., Chen, H., Gong, Y., Fan, M., Yang, H., Lal, R. and Kuzyakov, Y., 2012. Effects of 15 years of manure and inorganic fertilizers on soil organic carbon fractions in a wheat-maize system in the North China Plain. Nutr. Cycl. Agroecosyst 92, 21-33.

[47] Magahud, J. C., Badayos, R. B., Sanchez, P. B. and Cruz, P. C. S., 2015. Levels and sources of potassium, calcium, sulfur, iron and manganese in major paddy soils of the Philippines. International Journal of Philippine Science and Technology Vol.8 No.2, 1-8.

[48] Manahan, S. E., 2003. Toxicological Chemistry and Biochemistry, CRC Press, Limited Liability Company (LLC) $3^{\text {rd }}$ edition.

[49] Marzaioli, R., D' Ascoli, R., De Pascale, R. A. and Rutigliano, F. A. 2010. Soil quality in a Mediterranean area of Southern Italy as related to different land use types. Appl Soil Ecol 44 (3), 205-212.

[50] McCauley, A., Jones, C. and Jacobsen, C. D., 2009. Soil pH and organic matter. Nutrient management modules 8, \#4449-8. Montana State University Extension Service, Bozeman, Montana, pp. 1-12.

[51] Morgan, R., 2013. Soil, Heavy Metals and Human Health. In Brevik, E. C., Burgess, L. C., 2013. Soils and Human Health. Boca Raton. FL: CRC Press, pp. 59-80.

[52] Obata, H. and Omebayashi, M., 1997. Effects of cadmium on mineral nutrient concentrations in plants differing in tolerance for cadmium. Journal of Plant Nutrition 20, 97-105.

[53] Pan, J. J. 2004. Land resources survey and evaluation. Beijing: China Agriculture Press, pp. 27.

[54] Redondo-Gomez, S., Cantos, M., Mateos-Naranjo, E., Figueroa, M. and Troncoso, A., 2009. Heavy metals and trace element concentrations in intertidal soils of four estuaries of SW Iberian Peninsula. Soil \& Sediment Contamin 18, 320-327.

[55] Rodrigues, S. M., Cruz, N., Coelho, C., Henriques, B., Carvalho, L., Duarte, A. C., Pereira, E. and Romkens, P. F., 2013. Risk assessment for $\mathrm{Cd}, \mathrm{Cu}, \mathrm{Pb}$, and $\mathrm{Zn}$ in urban soils: chemical availability as the central concept. Environ Pollut $183,234-242$ 
[56] Sanita, L. T. and Gabbrielli, R., 1999. Response to cadmium n higher plants. Environmental and Experimental Botany 41, 105-130.

[57] Sebastian, A. and Prasad, M. N. V., 2015. Trace element management in rice. Agronomy 5, 374-404. doi: 10.3390/agronomy5030374.

[58] Sherene, T., 2010. Mobility and transport of heavy metals in polluted soil environment. Biological Forum-An International Journal 2 (2), 112-121.

[59] Smith, J. L. and Doran, J. W., 1996. Measurement and use of $\mathrm{pH}$ and Electrical Conductivity for Soil Quality Analysis. In Methods for Assessing Soil Quality; Doran JW and Jones AJ, eds. SSSA Spec. Publ. 49, Sci. Soc. Amer: Madison, Wisconsin, 169-185.

[60] Sohlenius, G. and Öborn, I., 2004. Geochemistry and partitioning of trace metals in acid sulphate soils in Sweden and Finland before and after sulphide oxidation. Geoderma $122,167-175$

[61] Soil Fertility Monitoring Tools. htm. 2014. Department of primary and industries. The state of Victoria. http://www.depi.vic.gov.au/...and...victorian...monitoringtools/soil-fertility.

[62] Soil Survey Division Staff. 1993. Soil Survey Manual. USDA Handbook 18, U. S. Government Printing Office, Washington, DC.

[63] Soltani, S. M., Hanafi, M. M., Wahid, S. A. and Kharidah, S. M. S., 2015. Zinc fractionation of tropical paddy soils and their relationships with selected soil properties. Chemical Speciation \& Bioavailability, Vol. 27 No.2, 53-61. http://dx.doi.org/10.1080/09542299.2015.1023091.

[64] SujathaDantu. 2010. Geochemical patterns in soils in and around Siddipet, Medak District, Andhra Pradesh, India. Environmental Monitoring and Assessment 170, 681-701.

[65] Tu, C., He, T., Liu, C., Lu, X. and Lang, Y., 2011. Accumulation of trace elements in agricultural topsoil under different geological background. Plant and Soil 349, 241-251.

[66] USDA. 2016. United States Department of Agriculture, Soil taxonomy. https://en.wikipedia.org/wiki/USDA-soiltaxonomy\#Example-of-classification-of-a-soil-type.

[67] USEPA. 2003. United State Environmental Protection Agency. Ecological soil screening level for aluminum. Interim final. OSWER Directive 9285. Washington DC, 7-60.

[68] USEPA. 2010. United State Environmental Protection Agency; Method 3050B. Acid Digestion of Sediments, Sludges and Soils, http://www.epa.gov/waste/hazard/ test methods/sw846/pdfs/3050b.pdf, accessed June/.

[69] Usman, A. R. A., Kuzyakov, Y. and Stahr, K., 2008. Sorption, desorption and immobilization of heavy metals by artificial soil. MSc. Thesis, University of Hohenhiem, Stuttgart.

[70] Vamerali, T., Bandiea, M. and Mosca, G., 2010. Field crops for phytoremediation of metal-contaminated land. A review.
Environ Chem Letter 8, 1-17.

[71] Van Reeuwijk, L. P. 2002. Procedures for soil analysis. Sixth edition. International soil reference and information centre. Food and agriculture organization of the United Nations.

[72] Vega, F. A., Covelo, E. F. and Andrade, M. L. 2005. Limiting factors for reforestation of mine spoils from Galicia (Spain). Land Degradation and Development 16, 27-36.

[73] Vega, F. A., Covelo, E. F., Andrade, M. L. and Marcet, P., 2004. Relationships between heavy metals content and soil properties in mine soils. Analytica Chimica Acta 524, 141150 .

[74] Vidal, J., Perez-Sirvent, C., Martinez-Sanchez, M. J., Navarro, M. C., 2004. Origin and behavior of heavy metals in agricultural Calcaric Fluvisols in semiarid conditions. Geoderma 121, 257-270.

[75] Virtanen, S., Simojoki, A., Rita, H., Toivonen, J., Hartikainen, H. and Yli-Halla, M., 2014. A multi-scale comparison of dissolved $\mathrm{Al}, \mathrm{Fe}$ and $\mathrm{S}$ in a boreal acid sulphate soil. Sciences of the Total Environment 499, 336-348.

[76] Wahsha, M., Bini, C., Fontana, S., Wahsha, A. and Zilioli, D. 2012. Toxicity assessment of contaminated soils from a mining area in Northeast Italy by using lipid peroxidation assay. J. Geochem. Explor 113, 112-117.

[77] Wangstrand, H., Eriksson, J., Oborn, I., 2007. Cadmium concentration in winter wheat as affected by nitrogen fertilization. European Journal of Agronomy 26, 209-214.

[78] Watson, M. E. and Brown, J. R., 2014. pH and lime requirement in soil analysis and methods. University of Minnesota. http://ral.cfans.umn.edu/soil-analysis-and methods/.

[79] WHO, 1996. World Health organization Guidelines for Drinking water quality. 2nd Ed., Vol.2, Health Criteria and Supporting Information, WHO, Geneva.

[80] Yang, M. G., Lin, X. Y. and Yang, X. E., 1998. Impact of Cd on growth and nutrient accumulation of different plant specied. Chinese Journal of Applied Ecology 19, 89-94.

[81] Zadrozny, P. and Nicia, P., 2009. Heavy metals in the peat soils of the Konecki County. Ecological Chemistry and Engineering Vol. 16 No. 9.

[82] Zayed, A. M. and Terry, N., 2003. Chromium in the environment: factors affecting biological remediation. Plant Soil 249, 139-156.

[83] Zhang, F. R. 2002. Soil geography. Beijing: China Agriculture Press, 17.

[84] Zhao, K. L., Liu, X. M., Xu, J. M. and Selim, H. M. 2010. Heavy metal contaminations in a soil-system: identification of spatial dependence in relation to soil properties of paddy fields. Journal of Hazardous Materials 181, 778-787. 